\title{
Çanakkale EImacık Yöresi Kalker Taşlarının Beton Agregası Olarak Uygunluğunun Araştırılması
}

\author{
Ferruh Altınsoy*, N. Şebnem Karahan, Rahman Çankaya, Ali Karabayır \\ Çanakkale Onsekiz Mart Üniversitesi, Çanakkale Teknik Bilimler Meslek Yüksekokulu, İnşaat ABD
}

\section{Özet}

Ülkemizde meydana gelen ve büyük yıkımlara yol açan depremlerden sonra inşa edilen yapıların özellikle depreme karşı dayanıklı olmaları çok önem kazanmıştır. Yapıların inşasında kullanılan yapı malzemelerinden en yaygın olanı betondur. Bundan dolayı da özellikle betonarme karkas yapılarda betonarme taşıyıcı yapı elemanlarının inşasında kullanılan betonarme betonun kalitesi çok önem kazanmıştır. Beton üretiminde kullanılan maddelerin \%65 ila \%75'ini agrega olarak adlandırılan kum, çakıl ve kırmataş oluşturmaktadır. Dolayısıyla nitelikli, istenilen basınç dayanımına sahip, çevresel etkilere karşı dirençli (durabilitesi yüksek) beton üretebilmek, agreganın 'TS 706 EN 12620-Beton Agregaları’ standardında aranan özelliklere uygun olmasına bağlıdır.

$\mathrm{Bu}$ çalışmada, şehir merkezine yakın bir bölgede konumlanan Çanakkale Elmacık Köyü mevkiinden standarda uygun olarak temin edilen kalker kayaçları ile bölgede faaliyet gösteren ÜSAT Yapı Madencilik San. ve Tic. A.Ş.' ye ait kırma eleme tesisinde üretilen kırmataş beton agregalarının mühendislik özellikleri boyut küçültme (kırma-eleme) numune azaltma ve boyuta göre sinıflandırma işlemine tabi tutulduktan sonra $\left(4 \mathrm{~mm}^{2}\right.$ gözlü elekten geçen ince agrega, $4 \mathrm{~mm}^{2}$ gözlü elekte kalan iri agrega olarak) sınıflandırılmıştır. Sınıflandırılan numunelere ilgili Türk Standartları ve Avrupa Standartlarına (TS, EN) göre incelenerek beton agregası olarak uygunluğu araştırılmıştır. Agrega numuneleri üzerinde tane büyüklügü dağılımı, parçalanma direnci tayini, tek eksenli basınç dayanımı, ince malzeme tayini, metilen mavisi, tane yoğunluğu, su emme, gevşek yığın yoğunluğu, özgül ağırlık, kuruma çekmesi deneyleri Çanakkale Onsekiz Mart Üniversitesi, Çevre ve Şehircilik Bakanlığı'ndan akredite edilmiş olan Çanakkale Teknik Bilimler Meslek Yüksekokulu Yapı Malzemeleri Laboratuvarı'nda gerçekleştirilmiştir.

Çanakkale Elmacık Köyü mevkiinden alınan numunelerin yapılan analizler sonucunda TS 706 EN 12620; Beton Agregaları standardında aranan özelliklere uygun olduğu ve kırmataşların hazır beton üretiminde beton agregası olarak kullanılabileceği tespit edilmiştir.

Anahtar Sözcükler: agrega, çanakkale elmacık, kireçtaşı, kireçtaşı özellikleri

\footnotetext{
*Sorumlu Yazar (Corresponding Author): Ferruh Altınsoy

(e-posta:faltinsoy@comu.edu.tr)

Ferruh Altınsoy’un, bu çalışması Çanakkale Onsekiz Mart Üniversitesi Bilimsel Araştırma Proje birimi tarafından desteklenmiştir. Proje numarası: FAY-2016-891
} 


\title{
The Investigation of Conformity as a Concrete Aggregate of The Limestones of Çanakkale Elmacık Region
}

\begin{abstract}
It has become very important for the constructions which have been built after the earthquakes that have led to great destructions in our country to be particularly resistant to earthquakes. One of the most common building materials used in the constructions of buildings is concrete. Therefore, the quality of the concrete has gained attention.. $65-75 \%$ of the materials used in concrete production are composed of sand, gravel and crushed stone called aggregate. Therefore, being able to produce concrete with high quality, durability and environmental resistance depends on the properties and the quality of aggregate according to TS 706 EN 12620-Concrete Aggregates standards.
\end{abstract}

In this study, after the limestone rocks obtained in accordance with the standards in Çanakkale Elmacik Village located near the city center and the engineering properties of the crushed stone concrete aggregates produced in the crushing screening plant of the USAT Building Mining Industry and Trading Inc which operates in the region are subjected to the classification process according to the size downscaling (crushing-elimination), sampling reduction and size, they are classified (as fine aggregate passing through a $4 \mathrm{~mm}$ square- mesh screen and coarse aggregate remaining in $4 \mathrm{~mm}$ square- mesh screen). Classified samples have been examined according to Turkish Standards and European Standards (TS, EN) and their suitability has been studied as a concrete aggregate. The experiments of the particle size distribution on aggregate samples, the fracture resistance determination, the uniaxial compressive strength, the fine material determination, the methylene blue, the grain density, the water absorption, the loose bulk density, the specific gravity and the desiccation shrinkage tests have been carried out in the Laboratory of Construction Materials of Çanakkale Onsekiz Mart University, Vocational School of Technical Sciences, which was accredited by the Ministry of Environment and Urban Planning.

The fact that samples taken from Çanakkale Elmacık Village site are suitable to meet the requirements in the Concrete Aggregates standard of TS 706 EN 12620 as a result of the analyses realized and the crushed stone can be used as a concrete aggregate in the production of ready mixed concrete has been determined.

Keywords: aggregate, çanakkale elmacık, limestone, properties of limestone

\section{Giriş}

Günümüzde hızla artan nüfusa bağlı olarak kentlerde yapılaşma ihtiyacı da ortaya çıkmıştır. Ülkemizde yaşanan ve büyük yıkımlara sebep olan depremler sonucunda daha güvenli ve dayanıklı yapıların inşa edilme zorunluluğu vardır. Beton dünyada olduğu gibi ülkemizde de en yaygın kullanılan yapı malzemesidir. Betonun mekanik özellikleri üzerinde en etkili olan, çimento-agrega aderansıdır. Aderansdaki artış, betonun dayanımı ve kohezyonu arttırmakla birlikte plastik ve sünek davranışı kısıtlamaktadır. Beton bileşenlerinin yaklaşık \%60 ila \%75'ini agrega oluşturmaktadır. Taze ve sertleşmiş beton özelliklerini etkileyen başlıca agrega özellikleri olarak; gradasyon, maksimum agrega tane büyüklüğü, agrega tane şekli, mevcut nem miktarı ve agreganın su emme kapasiteleri, birim ağırlık, özgül ağırlık, reaktif 
silika içeriği, zararlı maddelerin miktarı, mekanik özellikleri ve 1sısal özellikleri sayılabilir (Erdoğan, 2004). Bu nedenle betonda kullanılacak agregalardan alınan numuneler üzerinde deneysel çalışmalar yapılarak agreganın özelliklerinin belirlenmesi gerekmektedir. Agrega üretimi olarak günümüzde taş ocakları her geçen gün önem kazanmaktadır (Yılmaz ve Arıŏlu, 2006). Agregaların çıkartıldığı ana kayacın özelliklerinin bilinmesi beton üretimindeki kullanımları açısından önemlidir.

$\mathrm{Bu}$ çalışmada, Çanakkale Elmacık yöresi sınırları içinde yer alan çeşitli kalker taş ocaklarından kırılmış ve kırılmamış numuneler temin edilerek numunelerin fiziksel ve mekanik özellikleri incelenerek, TS 706 EN 12620 "Beton Agregaları" standardına uygunluğu ile elde edilen agregaların beton agregası olarak kullanılıp kullanılmayacağının tespiti amaçlanmıştır.

\section{Materyal ve Metot \\ 2.1.Materyal}

Bu çalışmada Çanakkale Merkez'inin güney doğusunda yer alan ve merkezden yaklaşı $20 \mathrm{~km}$ uzaklıkta bulunan Elmacık Köyü mevkiindeki kalker kayaçlardan elde edilen agregalar kullanılmıştır (Şekil 2.1a ve 2.1b). Şekil 2.2a ve 2.2b.'de Elmacık Köyü mevkii taş ocaklarından standartlara uygun numune alımı gösterilmektedir.

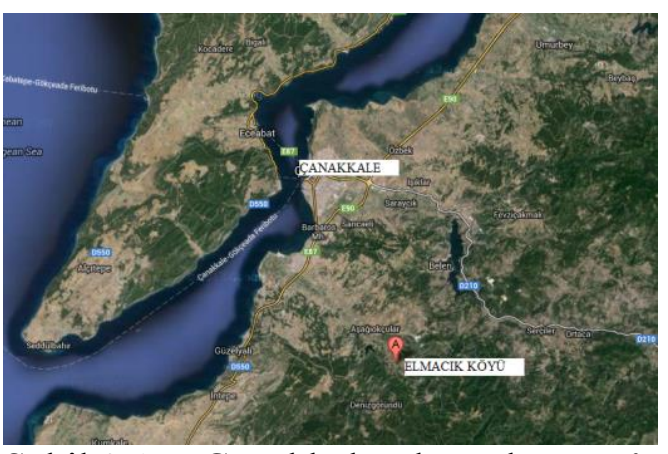

Şekil 2.1a. Çanakkale Elmacık Köyü’nün yeri

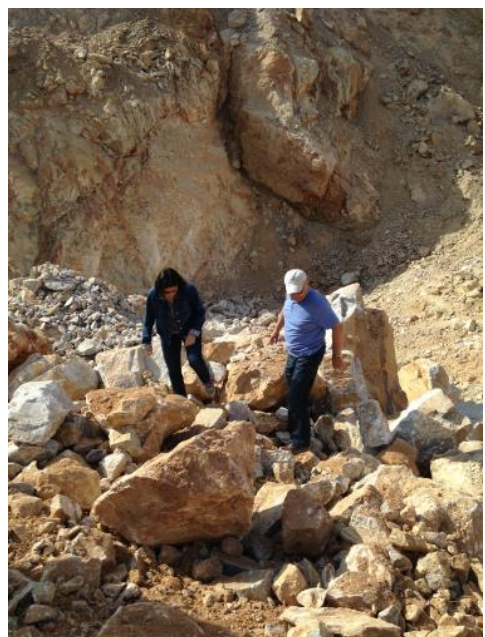

Şekil 2.2a. Elmacık Köyü mevkii taş ocaklarından numune alımı

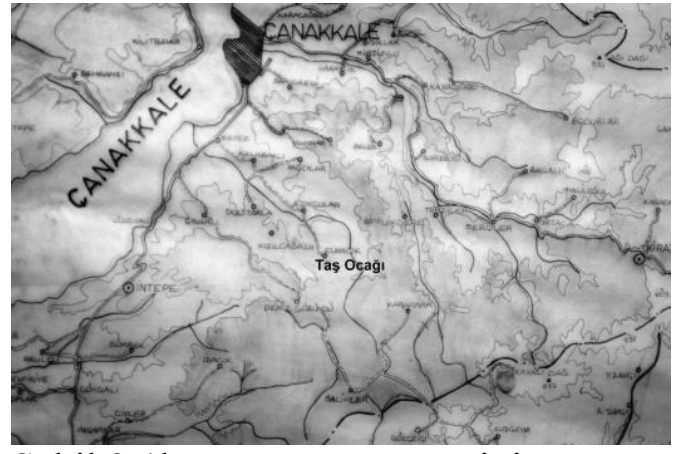

Şekil 2.1b. Taş ocağının yerini gösteren harita

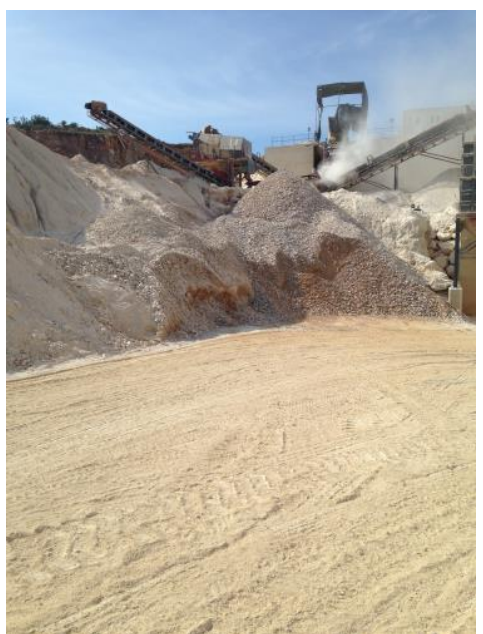

Şekil 2.2b. Taş ocağına ait genel görüntü 


\subsection{Metot}

Çalışmanın ilk aşamasında, Çanakkale Elmacık Köyü mevkiinde bulunan kalker taş ocaklarında incelemeler yapılmış ve ocaktan elde edilen numuneler tek eksenli basınç dayanımının yapılabilmesi için küp şeklinde kesilmiştir ve standartların öngördüğü diğer deneyler için 0-5 mm, 5-15 mm ve 15-22 mm'lik olmak üzere üç ayrı şekilde gruplandırılmıştır. Hazırlanan tüm numuneler deneylerin yapılabilmesi için ÇOMÜ Çanakkale Teknik Bilimler Meslek Yüksekokulu Yapı Malzemeleri Laboratuvarı'na getirilmiştir. Standartlarda belirtilen miktar ve şekillerde hazırlanan numuneler üzerinde tane büyüklüğü dağılımı, Los Angeles ile parçalanma direnci tayini, darbe ile parçalanma direnci tayini, tek eksenli basınç dayanımı, ince malzeme tayini, metilen mavisi, tane yoğunluğu, su emme ve kuruma çekmesi deneyleri yapılmıştır.

Agregaların tane büyüklügünü belirlemek için (granülometri) TS EN 933-1 standardı kullanılmış ve üç gruptan da 5000 g'lık numuneler üzerinde deneyler yapılmıştır. Agregalarda parçalanma direncini tayin edebilmek için TS EN 1097-2 standardında belirtilen iki yöntem kullanılmıştır. Los Angeles deney metodu ile parçalanma direnci tayini için iki ayrı grupta 5000 g'lık numuneler üzerinde çalışılmıştır. Bu yöntemde bir tambur içerisine toplam ağırlıkları $4710 \mathrm{~g}$ olan 11 adet bilye atıldıktan sonra 500 devir yapacak şekilde tambur döndürülmüş ve ağırlık kaybı belirlenmiştir. Darbe deneyi ile parçalanma direncinin tayininde ise iki grup numune bir arada kullanılarak standartta öngörüldüğü ş̧ekilde deney üç kez tekrarlanarak yapılmıştır. Ocaktan alınan iri numuneler 70x70x70 mm boyutlarında kesilerek hazırlanmış ve küp formuna getirildikten sonra TS EN 1926 standardında belirtildiği şekilde gerçekleştirilmiştir. Deneyler 5 ayrı numune üzerinde uygulanmıştır. Agregalarda bulunan ince malzemenin tayini için 0-5 mm'lik grup agrega kullanılmıştır. Deney, 750 g'lık numune üzerinde TS EN 933-10 standardına göre yapılmıştır. Sıfır-5 mm'lik grup agrega üzerinde TS EN 933-9 standardına uygun olarak metilen mavisi deneyi yapılmıştır. Agregalardaki tane yoğunluğunu belirlemek için TS EN 1097-6 standardı kullanılmıştır. Üç grup agrega üzerinde yapılan deneyler için, 0-5 mm'lik grup 1000 g'llk ve 5-15 mm, 15-22 mm'lik gruplar ise 2000 g'lık numuneler şeklinde hazırlanmış ve ikişer kez deneyler tekrarlanmıştır. Üç grup agreganın su emme değerlerinin bulunası için TS EN 1097-6 standardı kullanılmıştır. İkişer kez tekrarlanan deney sonucunda ortalama değerler hesaplanmıştır. Gevşek yığın yoğunluğu deneyi üç grup numune üzerinde uygulanmıştır. TS EN 1097-3 standardına uygun olarak deneyler yapılmıştır. Kuruma büzülme deneyi ise; hazırlanan 50x50x200 mm'lik üç prizma üzerinde TS EN 1367-4 standardına göre yapılmıştır. Agregaların yassılık indeksinin belirlenmesi için, deney 31,5-4 mm arasında kalan agrega numuneleri üzerinde uygulanmıştır. Deney, TS EN 933-3 standardına göre yapılmıştır.

\section{Bulgular ve Tartışma}

\subsection{Tane büyüklüğü dağılımına ilişkin bulgular}

Gradasyon, taze betonun işlenebilme özelliği ve sertleşmiş betonun dayanım, durabilite, birim ağırlık, büzülme gibi önemli özellikleri ve ekonomikliği üzerinde etkilidir (Erdoğan, 2004). Bundan dolayı beton yapımında kullanılacak agregaların büyüklüklerini belirleyerek uygun bir gradasyonda kullanabilmek gereklidir.

0-5 mm, 5-15 mm ve 15-22 mm'lik gruplar üzerinde 5000 g'lik numuneler ile deney yapılmış ve sonuçları Çizelge 3.1.'de, tane dağılımı (granülometri) eğrileri ise Şekil 3.1.'de verilmiştir. 
Altınsoy ve ark. 2017

Çizelge 3.1. Üç farklı grup agrega numunelerinin tane büyüklüğü dağılımı sonuçları

\begin{tabular}{|c|c|c|c|c|c|c|}
\hline \multirow{2}{*}{$\begin{array}{c}\text { Elek Çapları } \\
(\mathbf{m m})\end{array}$} & \multicolumn{3}{|c|}{ Elek Altına Geçen Malzeme Miktarı (\%) } & \multicolumn{3}{|c|}{ Elek Üstünde Kalan Malzeme Miktarı (\%) } \\
\hline & $15-22 \mathrm{~mm}$ & 5-15 mm & $0-5 \mathrm{~mm}$ & $15-22 \mathrm{~mm}$ & 5-15 mm & $0-5 \mathrm{~mm}$ \\
\hline 31,5 & 100 & 100 & 100 & 0 & 0 & 0 \\
\hline 16 & 74 & 100 & 100 & 26 & 0 & 0 \\
\hline 8 & 0,42 & 57,76 & 100 & 99,58 & 42,24 & 0 \\
\hline 4 & 0,36 & 0,28 & 85,78 & 99,64 & 99,62 & 14,22 \\
\hline 2 & 0,30 & 0,28 & 61,36 & 99,70 & 99,72 & 38,64 \\
\hline 1 & 0,28 & 0,26 & 44,38 & 99,72 & 99,74 & 55,62 \\
\hline 0,5 & 0,26 & 026 & 34,32 & 99,74 & 99,74 & 65,68 \\
\hline $\mathbf{0 , 2 5}$ & 0,26 & 0,26 & 25,82 & 99,74 & 99,74 & 74,18 \\
\hline \multirow{2}{*}{\multicolumn{4}{|c|}{$\begin{array}{r}\text { Toplam } \\
\text { İncelik Modülü }\end{array}$}} & 624 & 541 & 248 \\
\hline & & & & 6,24 & 5,41 & 2,48 \\
\hline
\end{tabular}

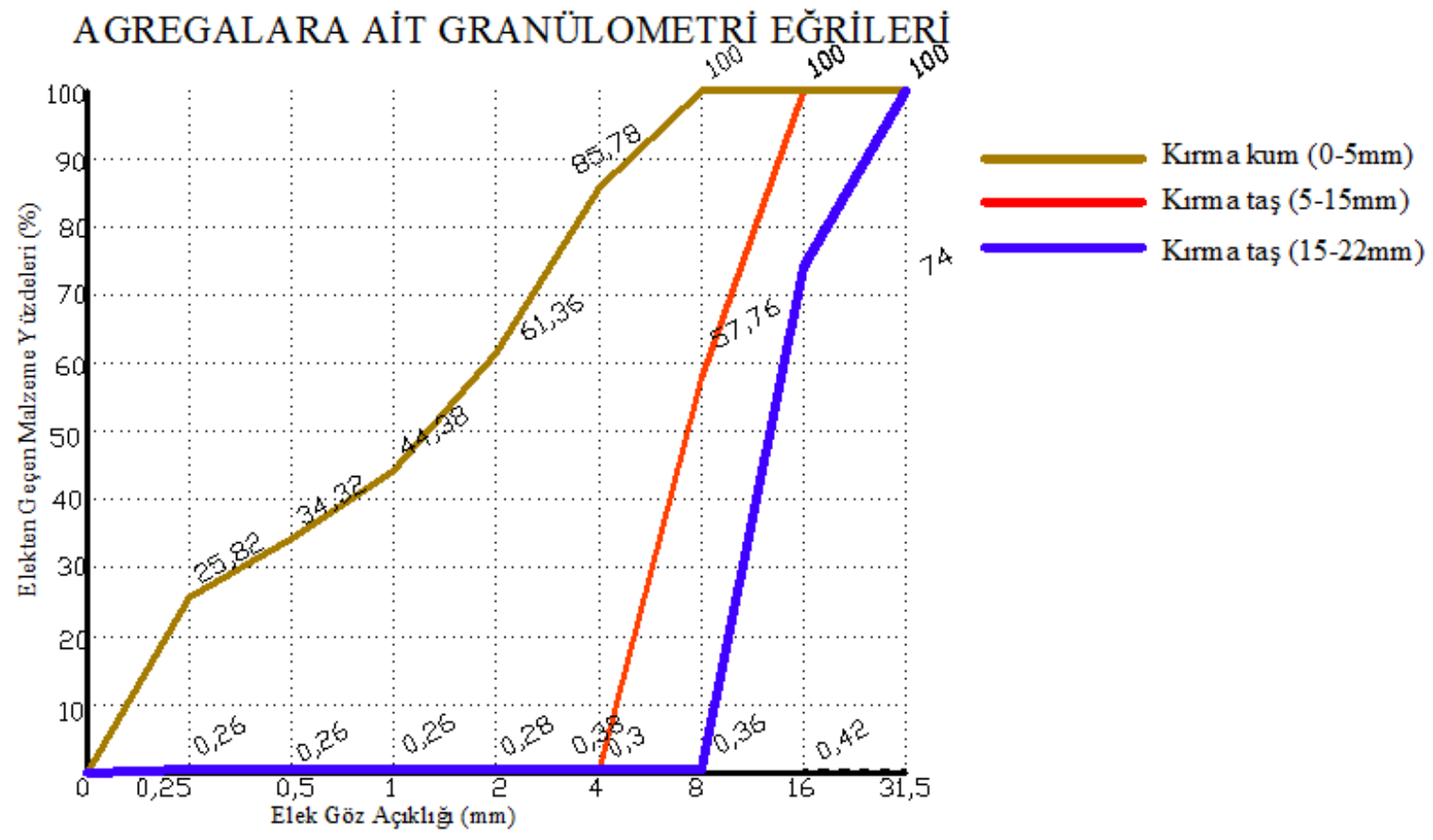

Şekil 3.1. Agrega numunelerinin tane büyüklüğü dağılımı grafikleri

\subsection{Parçalanma direnci}

Agregaların parçalanma direncini belirlemek için iki ayrı yöntem kullanılmıştır. Bunlardan birisi Los Angeles (LA) deney yöntemidir. Bu yöntem 5-15 mm ve 15-22 mm'lik gruplar üzerinde uygulanmış ve sonuçlar Çizelge 3.2.'de verilmiştir. Bu iki grup numuneden karma olarak hazırlanan karışım üzerinde yapılan parçalanma direnci deneyi (SZ) sonuçları ise Çizelge 3.3.'te verilmiştir. 
Çizelge 3.2. 5-15mm ve 15-22mm'lik grupların Los Angeles deneyi sonuçları

\begin{tabular}{|c|c|c|c|c|c|c|c|}
\hline \multicolumn{8}{|c|}{ 5-15 mm'lik grubun Los Angeles deney sonuçları } \\
\hline $\begin{array}{c}\text { Bilya } \\
\text { Sayıları }\end{array}$ & $\begin{array}{l}\text { Aralık } \\
\text { Sinıfları } \\
(\mathbf{m m})\end{array}$ & $\begin{array}{c}\text { Bilya } \\
\text { Yükü } \\
\text { Kütlesi } \\
\text { (g) }\end{array}$ & $\begin{array}{l}\text { İlk Ağırlık } \\
\text { (g) }\end{array}$ & $\begin{array}{c}500 \text { Devir } \\
\text { Sonu } \\
\text { Ağırlık } \\
(\mathrm{g})\end{array}$ & $\begin{array}{c}500 \text { Devir } \\
\text { Kaybı } \\
\text { Ağırlık } \\
(\mathrm{g})\end{array}$ & $\begin{array}{l}\text { Kayıp } \\
\text { Yüzdesi } \\
(\%)\end{array}$ & \multirow[t]{2}{*}{$L A=\frac{500-3650}{5000} \times 100=27 \%$} \\
\hline 11 & $5-15$ & 4710 & 5000 & 3650 & 1350 & 27 & \\
\hline \multicolumn{8}{|c|}{ 15-22mm'lik grubun Los Angeles deney sonuçları } \\
\hline $\begin{array}{c}\text { Bilya } \\
\text { Sayıları }\end{array}$ & $\begin{array}{l}\text { Aralık } \\
\text { Sinıfları } \\
(\mathbf{m m})\end{array}$ & $\begin{array}{c}\text { Bilya } \\
\text { Yükü } \\
\text { Kütlesi } \\
\text { (g) }\end{array}$ & $\begin{array}{l}\text { İlk Ağırlık } \\
\text { (g) }\end{array}$ & $\begin{array}{l}500 \text { Devir } \\
\text { Sonu } \\
\text { Ağırlık } \\
\text { (g) }\end{array}$ & $\begin{array}{c}500 \text { Devir } \\
\text { Kaybı } \\
\text { Ağırlık } \\
\text { (g) }\end{array}$ & $\begin{array}{l}\text { Kayıp } \\
\text { Yüzdesi } \\
(\%)\end{array}$ & \multirow[t]{2}{*}{$L A=\frac{500-3750}{5000} x 100=25 \%$} \\
\hline 11 & $15-22$ & 4710 & 5000 & 3750 & 1250 & 25 & \\
\hline
\end{tabular}

Çizelge 3.3. 5-15mm ve 15-22mm'lik gruplarından karma olarak hazırlanan numunenin Parçalanma Direnci deneyi sonuçları

\begin{tabular}{|c|c|c|c|c|c|c|}
\hline \multirow{2}{*}{$\begin{array}{c}\text { Elek } \\
\text { Çapları } \\
(\mathbf{m m})\end{array}$} & \multicolumn{4}{|c|}{ Elekten Geçen Malzeme Miktarları (g) } & \multirow{2}{*}{$\begin{array}{l}\text { Malzeme miktarlarının } \\
\text { kütlece oranları (\%) }\end{array}$} & \multirow{8}{*}{$s z=\frac{99}{5}=19,8 \%$} \\
\hline & 1.Numune & 2.Numune & 3.Numune & Ortalama & & \\
\hline 8 & 211 & 205 & 195 & 204 & 51 & \\
\hline 5 & 122 & 129 & 123 & 125 & 31,25 & \\
\hline 2 & 46 & 48 & 51 & 48 & 12 & \\
\hline 0,63 & 14 & 12 & 15 & 14 & 3,5 & \\
\hline 0,20 & 7 & 3 & 6 & 5 & 1,25 & \\
\hline & & & & Toplam & 99 & \\
\hline
\end{tabular}

Gruplara ait parçalanma direnci tayini deney sonuçlarına göre referans metot olarak bilinen Los Angeles deney sonuçlarına göre her iki grubun da kategorisi belirlenmiştir. Buna göre 515 mm'lik grubun kayıp yüzdesi $\leq 30$ olduğundan kategorisi LA30, 15-22 mm'lik grubunki ise $\leq 25$ olduğundan kategorisi ise LA25 olarak belirlenmiştir. Alternatif metot olarak bilinen Darbe Deneyi sonucuna göre ise kategorisi SZ22 olarak tespit edilmiştir. Numuneler üzerinde yapılan iki ayrı deney sonuçları ve belirlenen kategoriler birbirleri ile uyumlu ve beklenen bir sonuç olarak değerlendirilmektedir.

\subsection{Tek eksenli basınç dayanımı}

Betonda kullanılacak normal ağırlıklı agregaların basınç dayanımının 1500-2000 kgf/cm² arasında olması istenmektedir (Erdoğan, 2004). Ayrıca agreganın basınç dayanımlarının en az $600 \mathrm{kgf} / \mathrm{cm}^{2}$ olması da gerekmektedir. Basınç dayanımının $1000 \mathrm{kgf} / \mathrm{cm}^{2}$ den az olması halinde, kuşkulu durumlarda veya yapay agregalarda aşınmaya dayanıklılık deneyleri sonuçlarına bakılmaktadır. Dolayısıyla agregaların tek eksenli basınç dayanımı deney sonuçları, agregaların beton içerisindeki dayanımları ile ilgili olarak bilgi verebilmektedir. 70x70x70 mm'lik hava kurusu küpler üzerinde yapılan tek eksenli basınç deneyi sonuçları Çizelge 3.4.'te verilmiştir. Buradan da anlaşılacağı gibi değerler $1000 \mathrm{kgf} / \mathrm{cm}^{2}$ 'ini altında ancak $600 \mathrm{kgf} / \mathrm{cm}^{2}$ 'nin üzerinde çıkmıştır. Bundan dolayı da diğer deney sonuçlarına bakılarak değerlendirilmesi uygun olacaktır.

Çizelge 3.4. Tek eksenli basınç deneyi sonuçları

\begin{tabular}{|c|c|c|c|c|}
\hline Numune No & Ölçüler & Numunenin Durumu & Kırılma Kuvveti (kgf) & Basınç Dayanımı $\left(\mathrm{kgf} / \mathrm{cm}^{2}\right)$ \\
\hline 1 & \multirow{5}{*}{$70 \times 70 \times 70 \mathrm{~mm}$} & \multirow{5}{*}{ Hava kurusu } & 37248 & 760,16 \\
\hline 2 & & & 34592 & 705,96 \\
\hline 3 & & & 44270 & 903,47 \\
\hline 4 & & & 38396 & 783,59 \\
\hline 5 & & & 38726 & 790,33 \\
\hline & & Ortalama & 38646 & 788,702 \\
\hline
\end{tabular}




\subsection{Agregalarda ince malzeme}

Y1kanabilir ince maddeler agregalarda kısitlı miktarda bulunması istenen maddelerdendir. İçerisinde yıkanabilir madde miktarı çok olan agregaların beton içerisinde kullanılması betonun mukavemetini azalttığı, karma suyu ihtiyacını arttırdı $\breve{g}$, taze betonun işlenebilirliğini azalttığı, çimento ile arasındaki bağı zayıflattığı, betonun dayanım ve dayanıklılığını azalttığı, betonda büzülmeyi (rötreyi) artırdığı için sakıncalıdır.

İnce agrega (0/5) numune üzerinde yapılan ince malzeme oranı tayini deney sonuçları (MY) Çizelge 3.5.'te verilmiştir. Bulunan deney sonuçlarına göre kategorisi f10 olarak tespit edilmiştir.

Çizelge 3.5. İnce malzeme oranı tayini deney sonuçları

\begin{tabular}{|c|c|c|c|c|}
\hline Agrega Cinsi & İlk Ağırlık (g) & $\begin{array}{c}\text { Deney Sonrası Ağırlık } \\
(\mathbf{g})\end{array}$ & $\begin{array}{c}\text { Ağırlıkça İnce } \\
\text { Malzeme Oranı (\%) }\end{array}$ & \multirow{2}{*}{$M Y=\frac{750-675}{750}=10 \%$} \\
\hline İnce Agrega (0/5) & 750 & 675 & 10 & \\
\hline
\end{tabular}

\subsection{Metilen mavisi deneyine ait bulgular}

İnce agregalardaki çok ince malzemenin durumu değerlendirilip zararlı olup olmadığına karar verilirken kullanılan yöntemlerden biri de metilen mavisi deneyindir. Standarda uygun olarak ince agreganın deneye tabi tutulduğunda metilen mavisi deneyinin belirtilen alt sınır değerinden daha küçük bir değer vermesi gerekmektedir (Şimşek, 2004). Standarda uygun olarak yapılan deney sonuçları (MB) Çizelge 3.6.'da verilmiştir.

Çizelge 3.6. Metilen mavisi deney sonuçları

\begin{tabular}{|c|c|c|}
\hline \multicolumn{3}{|l|}{ 10g/lt'lik Metilen Mavisi Cözeltisi } \\
\hline Metilen Mavisi Tozunun Kütlesi (g) $\mathrm{M}_{\mathrm{h}}$ & \multicolumn{2}{|r|}{5} \\
\hline Kurutulmuş Metilen Mavisi Tozunun Kütlesi $(\mathrm{g}) \mathrm{M}_{\mathrm{g}}$ & \multicolumn{2}{|r|}{4,88} \\
\hline$\left.\omega=\left\{\left(M_{4}-M_{g}\right) / M_{g}\right\} \times 100(\%)\right]$ & \multicolumn{2}{|r|}{2,46} \\
\hline Metilen Mavisi Miktar $1((100+\omega) / 10) \pm 0,01(\mathrm{~g})$ & \multicolumn{2}{|r|}{10,25} \\
\hline \multicolumn{3}{|l|}{ MB Hesabı } \\
\hline Kum Kütlesi (g) $\mathrm{M}_{1}$ & 200 & \multirow{2}{*}{$M B=\frac{V_{2}}{M_{1}} x 10=\frac{10}{200} x 10=0,5 \mathrm{~g} / \mathrm{kg}$} \\
\hline İlave Edilen Boya Çözeltisi Hacmi (ml) $\mathrm{V}_{1}$ & 10 & \\
\hline
\end{tabular}

\subsection{Agregalarda tane yoğunluğu, su emme, gevşek yığın yoğunluğu, özgül ağırlık ve} boşluk hacmi

Agrega taneleri arasında kusurlu ve keskin köşeli tanelerin fazla olması boşluğu artırdığından dolayı birim hacim ağırlığını olumsuz yönde etkilemektedir. Birim hacim ağırlığı yüksek olan bir agrega ile üretilen betonun dayanımı, dayanıklılı̆̆ ve taşıma gücü fazladır. Beton agregalarının birim ağırlıklarının 1,3-1,85 kg/ $\mathrm{dm}^{3}$ arasında değiştiği bilinmektedir (Çiftçi, 2015). Ayrıca agreganın su emme miktarı da agreganın özelliklerini etkilemektedir. Su emme yüzdesi yüksek olan agreganın betonda kullanılması beton dayanımını ve dayanıklılığını azaltır. Beton agregasının EN 1097-6'ya uygun olarak tayin edilmiş olan su emme oranı, $\% 1$ 'den daha büyük değilse agreganın donma-çözünme etkisine dirençli olduğu kabul edilebilir. Ancak, donma-çözülmeye dayanıklılık için yeterli olan birçok agrega, daha yüksek emme değerlerine sahiptir. Normal ağırlıklı agregalar 2,4-2,8 özgül ağırlığa sahip olan agregalardır. Hafif agregaların özgül ağırlıkları 2,4'ten küçük, ağır agregaların ise 2,8'den 
büyüktür. Beton yapımında kullanılan agregaların özgül ağırlıkları genellikle 2,55-2,70 arasında yer almaktadır (Erdoğan, 2004).

0-5 mm, 5-15 mm ve 15-22 mm'lik agrega numuneleri üzerinde yapılan deney sonuçları Çizelge 3.7. ve 3.8.'de verilmiştir. Agrega numuneleri üzerinde yapılan deneyler sonucunda su emme değerleri 0-5 mm'lik grupta $\% 0,88,5-15 \mathrm{~mm}$ 'lik grupta $\% 0,67$ ve $15-22 \mathrm{~mm}$ 'lik grupta \%0,63 olarak bulunmuştur. Bu değerler standartta belirtilen değer olan \%1'den küçük olduklarından agregaların donma çözünme etkisine karşı dirençli oldukları kabul edilebilir. Bulunan özgül ağırlık değerleri ise 2,73, 2,64 ve 2,58'dir ve betonda kullanılacak agregalar için olması gereken özgül ağırlık değerlerini de sağlamaktadırlar.

Çizelge 3.7. Tane yoğunluğu ve su emme deney sonuçları

\begin{tabular}{|c|c|c|c|c|c|c|}
\hline & \multicolumn{2}{|c|}{ 0-5 mm'lik grup } & \multicolumn{2}{|c|}{ 5-15 mm'lik grup } & \multicolumn{2}{|c|}{ 15-22 mm’lik grup } \\
\hline Piknometre+Su+Malzeme Kütlesi (g) $\mathrm{M}_{2}$ & 5843 & 5842 & 6619 & 6620 & 6602 & 6599 \\
\hline Piknometre+Su Kütlesi (g) $\mathrm{M}_{3}$ & 5201 & 5201 & 5363 & 5363 & 5363 & 5363 \\
\hline Malzeme DKY Kütlesi (g) $\mathrm{M}_{1}$ & 1008,5 & 1009 & 2013 & 2013,5 & 2014 & 2011 \\
\hline Malzeme Etüv Kurusu Kütlesi (g) $\mathrm{M}_{4}$ & 1000 & 1000 & 2000 & 2000 & 2000 & 2000 \\
\hline \multirow{2}{*}{$\begin{array}{l}\text { Görünür Tane Yoğunluğu } \\
\rho_{=}=M_{4} /\left[M_{4}-\left(M_{2}-M_{2}\right)\right]\end{array}$} & 2,79 & 2,79 & 2,69 & 2,69 & 2,63 & 2,62 \\
\hline & \multicolumn{2}{|c|}{2,79} & \multicolumn{2}{|c|}{2,69} & \multicolumn{2}{|c|}{2,63} \\
\hline \multirow{2}{*}{$\begin{array}{l}\text { Etüv Kurusu Tane Yoğunluğu } \\
\rho_{\text {rs }}=M_{4} /\left[M_{2}-\left(M_{2}-M_{2}\right)\right]\end{array}$} & 2,73 & 2,72 & 2,64 & 2,64 & 2,58 & 2,58 \\
\hline & \multicolumn{2}{|c|}{2,73} & \multicolumn{2}{|c|}{2,64} & \multicolumn{2}{|c|}{2,58} \\
\hline \multirow{2}{*}{$\begin{array}{l}\text { DKY Tane Yoğunluğu } \\
\rho_{m s y}=M_{1} /\left[M_{1}-\left(M_{2}-M_{2}\right)\right]\end{array}$} & 2,75 & 2,74 & 2,66 & 2,66 & 2,6 & 2,59 \\
\hline & \multicolumn{2}{|c|}{2,75} & \multicolumn{2}{|c|}{2,66} & \multicolumn{2}{|c|}{2,6} \\
\hline \multirow{2}{*}{$\begin{array}{l}\text { Su Emme Oran1 } \\
W A_{24}=\left(M_{1}-M_{4}\right) / M_{4} x 100\end{array}$} & 0,85 & 0,9 & 0,65 & 0,68 & 0,7 & 0,55 \\
\hline & \multicolumn{2}{|c|}{0,88} & \multicolumn{2}{|c|}{0,67} & \multicolumn{2}{|c|}{0,63} \\
\hline
\end{tabular}

Çizelge 3.8. Gevşek yığın yoğunluğu, özgül ağırlık ve boşluk oranı tayini deney sonuçları

\begin{tabular}{|c|c|c|c|c|c|c|}
\hline \multirow[b]{2}{*}{ Agrega Türü } & \multicolumn{3}{|c|}{ Ölçü Kabı } & \multirow{2}{*}{$\begin{array}{c}\begin{array}{c}\text { Gevşek } \\
\text { Yoğunluk } \\
\left(\mathbf{k g} / \mathbf{d m}^{3}\right)\end{array} \\
B=\frac{M_{2}-M_{2}}{V}\end{array}$} & \multirow[b]{2}{*}{$\begin{array}{c}\text { Kuru Özgül } \\
\text { Ağırlık } \\
\text { A }\end{array}$} & \multirow[b]{2}{*}{$\begin{array}{c}\begin{array}{c}\text { Bossluk } \\
\text { Hacmi Oranı } \\
(\%) \\
\frac{A-B}{A} \times 100\end{array}\end{array}$} \\
\hline & $\begin{array}{c}\text { Ölçü Kabının } \\
\text { Kütlesi (kg) } \\
M_{1}\end{array}$ & $\begin{array}{c}\text { Malzeme+Kap } \\
\text { Kütlesi(kg) } \\
\mathbf{M}_{2}\end{array}$ & $\begin{array}{c}\underset{V}{\operatorname{Hacmi}}\left(\mathbf{d m}^{3}\right) \\
\end{array}$ & & & \\
\hline $0-5 \mathrm{~mm}$ & 3,586 & 8,556 & 3 & 1,66 & 2,73 & 39 \\
\hline $5-15 \mathrm{~mm}$ & 3,586 & 7,825 & 3 & 1,41 & 2,64 & 47 \\
\hline $15-22 \mathrm{~mm}$ & 3,586 & 7,760 & 3 & 1,39 & 2,58 & 46 \\
\hline
\end{tabular}

\subsection{Agregalarda kuruma büzülmesi bulguları}

Agrega özellikleri sebebiyle betonda hasara yol açan büzülme çatlakları oluşması halinde, gerektiğinde betonarme betonunda kullanılacak agregaların kuruma büzülmesi, ilgili standarda göre bulunması gerekmektedir. Buna göre hazırlanan 3 adet prizma üzerinde yapılan deney sonuçları ve ortalama değerleri Çizelge 3.9.'da verilmiştir. Standarda uygun olarak numunenin deneye tabi tutulduğunda kuruma büzülmesi değerinin \% 0,075'i aşmamasi gerektiği kabul edilmektedir.

Çizelge 3.9.'dan da görüleceği gibi bulunan değer \%0,015'dir. Bu değer standartta verilen sınır değerden oldukça küçüktür ve bu da agregaların kuruma büzülmesi açısından uygun olduğunu göstermektedir. 
Altınsoy ve ark. 2017

Çizelge 3.9. Kuruma büzülmesi deney sonuçları

\begin{tabular}{|c|c|c|c|c|}
\hline Numune No & $\begin{array}{c}\text { w-d } \\
(\mathbf{m m})\end{array}$ & $\begin{array}{c}\mathbf{l} \\
(\mathbf{m m})\end{array}$ & \multicolumn{2}{|c|}{$\begin{array}{c}\text { Kuruma Çekmesi } \\
(\%)\end{array}$} \\
\hline 1 & 0,05 & 200 & 0,025 & \multirow{4}{*}{$s=\frac{w-d}{l} \times 100$} \\
\hline 2 & 0,01 & 200 & 0,005 & \\
\hline 3 & 0,03 & 200 & 0,015 & \\
\hline \multicolumn{3}{|c|}{ Ortalama } & 0,015 & \\
\hline
\end{tabular}

\subsection{Agregalarda yassılık indeksi değerleri}

Agrega tanelerinin şekil ve biçimleri, taze betonun işlenebilme özelliği ve su ihtiyac1 açısından çok önemlidir. Agregaların uygun olabilmesi için şekillerinin küre veya küp şekline yakın olmaları gerekmektedir. Uzun silindir ya da yassı şeklinde olan agregalar kusurlu olarak kabul edilir ve bu şekilde olan agregalar betonun işlenebilme özelliğini azaltır ve kolay kırılır. Bundan dolayı agregaların geometrik şekillerinin belirlenmesi ve uygunluğunun gösterilmesi gerekmektedir.

Deney 31,5-4 mm'lik elekler arasında kalan numuneler üzerinde uygulanmıştır. Standarda göre hazırlanan numuneler farklı açıklıklardaki silindirik çubuklu eleklerden elenerek tartılmıştır. Hesaplanan sonuçlar ve yassılık indeksi değeri Çizelge 3.10.'da verilmiştir.

Çizelge 3.10. Yassılık indeksi tayini deney sonuçları

\begin{tabular}{|c|c|c|c|c|}
\hline \multicolumn{5}{|l|}{ Malzeme Bilgileri } \\
\hline Kaynak: Elmacık Yöresi & Boyut: $5 / 15$ & Numune Kütlesi (g): 130 & İşlem Dışı Kütl & 4,00 \\
\hline \multicolumn{2}{|c|}{ 80mm Elek Üzerinde Kalan: 0,00} & \multicolumn{3}{|c|}{ 4mm Elek Altına Geçen Malzeme Kütlesi (g): 4,00 } \\
\hline \multicolumn{2}{|l|}{ Deney Elekleriyle Eleme } & \multicolumn{3}{|c|}{ Silindirik Çubuklu Eleklerle Eleme } \\
\hline $\begin{array}{l}\text { Tane Büyüklüğü } \\
\text { Fraksiyonu } \\
\text { d }_{i} / D_{\mathbf{i}}(\mathbf{m m})\end{array}$ & $\begin{array}{l}\mathbf{d}_{\mathrm{i}} / \mathbf{D}_{\mathbf{i}} \text { Tane Büyüklüğü } \\
\text { Fraksiyonu } \\
\mathbf{R}_{\mathbf{i}}(\mathbf{g})\end{array}$ & $\begin{array}{c}\text { Çubuklu Eleklerin } \\
\text { Anma Açıklığı (mm) }\end{array}$ & $\begin{array}{c}\text { Çubuklu Elekten } \\
\text { Geçen Malzemenin } \\
\text { Kütlesi } \\
\mathbf{M}_{\mathrm{i}}(\mathrm{g}) \\
\end{array}$ & $F_{i}=\frac{M_{i}}{R_{i}} \times 100$ \\
\hline $12,5 / 16$ & 140,00 & 8 & 24,00 & $17,14 \%$ \\
\hline $10 / 12,5$ & 327,00 & 6,3 & 33,00 & $10,09 \%$ \\
\hline $8 / 10$ & 362,00 & 5 & 127,00 & $35,08 \%$ \\
\hline $6,3 / 8$ & 295,00 & 4 & 109,00 & $36,95 \%$ \\
\hline $5 / 6,3$ & 158,00 & 3,15 & 51,00 & $32,28 \%$ \\
\hline $4 / 5$ & 20,00 & 2,5 & 4,00 & $20,00 \%$ \\
\hline$M_{1}=\Sigma R_{i}$ & 1302,00 & $M_{2}=\Sigma M_{i}$ & 348,00 & - \\
\hline \multicolumn{5}{|c|}{ Yassllık Yüzdesi= $F=M_{2} / M_{1} x 100=348 / 1302 x 100=26,73 \% \leq 35 ;{\text { Kategori } \mathbf{F l}_{35}}^{2}$} \\
\hline
\end{tabular}

\subsection{Tartışma}

Çanakkale Elmacık Yöresindeki taş ocağından alınan numuneler üzerinde çeşitli deneyler yapılmıştır. Agreganın elde edildiği kayaçlar üzerinde yapılan tek eksenli basınç deneyi sonucunda, diğer deneylerin de yapılmasının gerektiği tespitinde bulunulmuştur. Yapılan hem referans hem de alternatif metotlarda aşınma kaybı-çarpma dayanımı sonuçlarının tutarlı olduğu ve istenen şartları sağladığı görülmüş ve standartta belirtilen şekilde kategori belirlenebilmiştir. İnce malzeme deneyi sonucunda da standartta tanımlandığı şekilde kategori belirlenmiştir. Aynı zamanda metilen mavisi deneyi ile de sonuç desteklenmiştir. Tane 
yoğunluğu, özgül ağırlık ve su emme deney sonuçlarına bakıldığında da izin verilen sınırlar içerisinde kalındığı görülmüştür. Yapılan kuruma çekmesi deney sonucunun da standartta belirtilen sınırlar içerisinde kalınmış olduğu tespit edilmiştir. Son olarak yapılan yassılık indeksi değerlerinin de uygun olduğu görülmüştür.

\section{Sonuç}

Yapılan tüm test ve analiz sonuçları değerlendirildiğinde; Çanakkale Elmacık Yöresi kalker taş ocaklarından alınan numunelerin TS 706 EN 12620 standardında "Beton Agregaları" için belirlenen özelliklere sahip olduğu ve bu bölgedeki kalker taşlarının betonarme betonu üretiminde beton agregası olarak kullanılabileceği görülmüştür.

\section{Teşekkür}

Çanakkale İline bu sektörde katk1 sunmak için yapılan bu özgün çalışma, FAY-2016-891 no'lu proje ile Çanakkale Onsekiz Mart Üniversitesi BAP birimi tarafından desteklenmiştir. Proje bütçesi kapsamında deneysel çalışmalarda kullanılmak üzere ihtiyaç duyulan araç ve gereçlerin alımını BAP birimi çalışanlarınca titizlikle takip edilerek yapılmıştır. Araştırmaya konu olan Elmacık yöresindeki kalker taş ocakları ile ilgili saha çalışmalarının planlanmasında, araştırılmasında ve yürütülmesinde ilgi ve desteğini esirgemeyen saha ile ilgili engin bilgi ve tecrübelerinden yararlandığımız ÜSAT Yapı Madencilik San. ve Tic. A.Ş.'nin yöneticilerine, çalışanlarına, projeye katkı sunan herkese katkıları için teşekkür ederiz.

\section{Kaynaklar}

Çiftçi, E., 25.12.2015. Hazır Beton Agregaları.

http://www.csb.gov.tr/iller/dosyalar/dosya/il_webmenu12120.pdf

Erdoğan, T.Y., 2004. Sorular ve Yanıtlarıyla Beton Malzemeleri. Türkiye Hazır Beton Birliği, Ankara

Şimşek, O., 2004. Beton Bileşenleri ve Beton Deneyleri. Seçkin Yayıncılık, Ankara

TS 709 EN 12620, 2009. Beton Agregaları. Türk Standartları Enstitüsü, Ankara

TS EN 1097-2, 2010. Agregaların Mekanik ve Fiziksel Özellikleri İçin Deneyler, Bölüm 2: Parçalanma Direncinin Tayini İçin Metotlar. Türk Standartları Enstitüsü, Ankara

TS EN 1097-3, 1999. Agregaların Fiziksel ve Mekanik Özellikleri İçin Deneyler, Bölüm 3: Gevşek Yığın Yoğunluğunun ve Boşluk Hacminin Tayini. Türk Standartları Enstitüsü, Ankara 
Altınsoy ve ark. 2017

TS EN 1097-6, 2013. Agregaların Mekanik ve Fiziksel Özellikleri İçin Deneyler, Bölüm 6: Tane Yoğunluğu ve Su Emme Oranının Tayini. Türk Standartları Enstitüsü, Ankara

TS EN 1367-4, 2009. Agregaların Isıl ve Yıpranma Özellikleri İçin Deneyler, Bölüm 4: Kuruma Büzülmesinin Tayini. Türk Standartları Enstitüsü, Ankara

TS EN 1926, 2013. Doğal Taşlar-Deney Yöntemleri-Tek Eksenli Basınç Dayanımı Tayini. Türk Standartları Enstitüsü, Ankara

TS EN 933-1, 2012. Agregaların Geometrik Özellikleri için Deneyler, Bölüm 1: Tane Büyüklüğü Dağılımı Tayini-Eleme Metodu. Türk Standartları Enstitüsü, Ankara

TS EN 933-10, 2010. Agregaların Geometrik Özellikleri İçin Deneyler, Bölüm 10: İnce Malzeme Tayini-İnce Dolgu Malzemelerin Tane Büyüklüğüne Göre Sınıflandırılması. Türk Standartları Enstitüsü, Ankara

TS EN 933-3, 2012. Agregaların Geometrik Özellikleri İçin Deneyler, Bölüm 3: Tane Şekli Tayini-Yassılık Endeksi. Türk Standartları Enstitüsü, Ankara

TS EN 933-9, 2010. Agregaların Geometrik Özellikleri İçin Deneyler, Bölüm 9: İnce Malzeme Tayini-Metilen Mavisi Deneyi. Türk Standartları Enstitüsü, Ankara

Yılmaz, A., Arıoğlu, E., 2006. Taşocağında Üretim Maliyetlerinin Matematiksel Modelinin Oluşturulması ve Örnek Uygulama. IV. Ulusal Kırmataş Sempozyumu, Ed. A.E. Yüce, C. Kuzu, A. Güney ve M. Erdoğan, İstanbul. 265-276 